\title{
Performance of Selected Diploid Watermelon Pollenizers ${ }^{1}$
}

J.H. Freeman, G. A. Miller, S.M. Olson²

\section{Summary}

As seedless watermelons (Citrullus lanatus) increase in popularity, production is being shifted away from seeded watermelons. To achieve successful fruit set in triploid watermelons, a diploid watermelon cultivar must be planted as a pollen source. Multiple diploid cultivars were compared to determine their effectiveness as pollenizers. All pollenizer cultivars were planted within plots of triploid watermelon with buffers on all sides of the plots to contain pollen flow within individual plots. All pollenizer cultivars performed similarly and pollen flow was contained within experimental plots as indicated by minimal fruit set in check plots.

Over the last decade, the popularity of seedless watermelon [Citrullus lanatus (Thunb.) Matsum. and Nakai] has increased. During peak watermelon production in the U.S. in 2005 and 2006, seeded watermelons comprised only 22 to $23 \%$ of the market and averaged four to five cents less per pound than seedless (USDA, 2005-2006). When growers transfer acreage to seedless watermelon production, they must take into account that triploid watermelon plants do not produce enough viable pollen to pollinate themselves (Maynard, 1992; Maynard and Elmstrom, 1992). Diploid cultivars can provide the pollen for the triploid cultivar. To achieve optimal yields, $20 \%$ to $33 \%$ of the plants in the field should be diploid (Fiacchino and Walters, 2003; NeSmith and Duval, 2001). Traditionally, dedicated rows have been set aside for diploid cultivars (Figure 1). A wide range of pollenizer cultivars (Table 1 ) have now been designed to be planted in-row (Figure 2) with triploid plants. Eliminating dedicated row space in the field for pollenizers should increase the number of triploid plants and watermelons harvested per acre.

These pollenizer cultivars are relatively new, and the concept itself is new, thus, until our research, little work has been done comparing the attributes of these cultivars in this specific role. There are three basic types of pollenizer cultivars available: thin vine, bush type, and standard. The most important characteristics of these special pollenizers are: 1) proliferation of male flowers and pollen, 2) non-competitive growth habit, 3) and distinct fruit size or rind pattern. It is important that the cultivars

1. This document is HS1081, one of a series of the Horticultural Sciences Department, Florida Cooperative Extension Service, Institute of Food and Agricultural Sciences, University of Florida. Original publication date January 2007. Visit the EDIS Web Site at http://edis.ifas.ufl.edu.

2. J.H. Freeman, graduate student, Horticultural Science Department, Institute of Food and Agricultural Sciences, University of Florida, Gainesville; G. Miller, Area Vegetable Extension Specialist, Clemson University, Edisto Research and Education Center, Blackville, SC; and S.M. Olson, Professor, North Florida Research and Education Center - Quincy, Florida Cooperative Extension Service, Institute of Food and Agricultural Sciences, University of Florida, Gainesville, 32611.

The Institute of Food and Agricultural Sciences (IFAS) is an Equal Opportunity Institution authorized to provide research, educational information and other services only to individuals and institutions that function with non-discrimination with respect to race, creed, color, religion, age, disability, sex, sexual orientation, marital status, national origin, political opinions or affiliations. U.S. Department of Agriculture, Cooperative Extension Service, University of Florida, IFAS, Florida A. \& M. University Cooperative Extension Program, and Boards of County Commissioners Cooperating. Larry Arrington, Dean 
have high numbers of male flowers throughout the season in order to provide adequate pollen for fruit set in the triploid crop. It is important that the pollenizer growth habit does not compete with the triploids because at a 1:3 pollenizer to triploid ratio, the pollenizers competition will impact two thirds of the triploid plants. It has been shown that intra-specific competition can shift the size distribution and amount of fruit produced by the plant (Cushman et al., 2004; Motsenbocker and Arancibia, 2002; Sanders et al., 1999). Other important characteristics of the pollenizer cultivar are the size and rind pattern of the fruit, which enable a harvesting crew to distinguish marketable fruit from pollenizer fruit.

In the spring of 2005 and 2006, research was conducted by the University of Florida and Clemson University to compare the effectiveness of new pollenizer cultivars. Each cultivar was inter-planted within a plot of Supercrisp triploid watermelon. The pollenizer cultivars were planted between the triploid plants, but there was no extra space added for pollenizers. The spacing between pollenizers and triploid plants was twenty inches. All pollenizers were planted at a 1:3 pollenizer to triploid ratio except Companion, which was planted at the recommended 1:2 pollenizer to triploid ratio. A buffer was planted around each plot to contain pollen flow within the plot. The buffer ensured that each pollenizer could be judged on its ability to provide pollen to the triploid plants it was planted with, without interfering with neighboring plots. In 2005, three cultivars of pollenizers (Jenny, Mickylee, SP-1) were used, and in 2006, seven cultivars (Companion, Jenny, Mickylee, Patron, Pinnacle, Sidekick, SP-1) were used. Each experiment incorporated a plot that contained no pollenizers. In these plots, the triploid cultivar Tri-X Palomar was planted in place of the pollenizer to ensure that all plant populations remained similar, as did intra-specific competition. This was to serve as a check to show if there was pollen contamination from neighboring plots. At all locations and all years, plants were grown on raised beds covered with black polyethylene mulch. In all locations rows were spaced eight feet apart, and plants within rows were spaced three feet apart. Seedless watermelon yield and soluble solids data were taken at all locations in both years, and hollow heart measurements were taken at all locations in 2006.

\section{Results and Discussion}

Location had a significant effect on yield, but there were no significant interactions between cultivar and location, so all locations were combined (Table 5). All plots containing pollenizers had significantly greater yield than the check at all locations in both years. There were no significant differences in yield between pollenizer cultivars during 2005. Complete yield data can be seen in Tables 2 and 3. Significant differences in seedless watermelon yield were observed between pollenizer cultivars during 2006. Plots pollenized by Sidekick yielded the greatest at 58,252 lbs/acre but were not significantly different than plots pollenized by Patron, SP-1, Jenny, or Mickylee which yielded 56,854, 55,148, 55,135, and 53,213 lbs/acre, respectively (Table 3 ). Plots pollenized by Companion yielded the lowest, at 44,621 lbs/acre but were not significantly different from plots pollenized by Pinnacle or Mickylee, which yielded 47,618 and $53,213 \mathrm{lbs} / \mathrm{acre}$, respectively. At all locations in both years, pollenizer cultivar had a significant effect on number of melons, and all plots containing pollenizer cultivars produced significantly more melons than the check plots. There were no significant differences in the number of seedless fruits produced between pollenizers during both years. In 2006, pollenizer cultivar did not have a significant effect on hollow heart at the Citra, Florida and Blackville, South Carolina locations. The incidences of hollow heart at these locations were low overall, and this may be why there was no effect by the pollenizer. Pollenizer cultivar did have a significant effect on hollow heart at Quincy, Florida, and all pollenizer cultivars had significantly lower hollow heart as compared to the check plots. No significant differences in hollow heart were observed between pollenizer cultivars. At all locations in both years, pollenizer cultivar did not have a significant effect on soluble solids.

This research shows that some pollenizer cultivars perform better than others. The only cultivar that showed questionable performance was Companion. Due to its growth and flowering habit, it may not produce enough flowers and pollen at the end 
of fruit set in the triploid crop. Companion becomes overgrown by triploid plants near the end of the season and may not have flowers that are readily detectable by pollinators. This illustrates that pollenizers must be able to continue growing and producing flowers even when they are in close association with triploid plants. Of the cultivars tested, it appears that any of the thin vine or standard type pollenizers (Jenny, Mickylee, Patron, Pinnacle, Sidekick, and SP-1) would be a good choice. Some of the tested pollenizers (Mickylee, Jenny, and Pinnacle) can be harvested and sold if the grower has a market for seeded watermelons. If growers have a strong market for seeded melons, the use of in-row pollenizers may not be warranted, and the previous system of dedicated pollenizer rows may still be used. The pollenizers costs vary greatly and must be taken into consideration. Of the pollenizers previously recommended, cultivar selection should be based on economic and marketing concerns.

\section{References}

Cushman, K. E., D. H. Nagel, T. E. Morgan, P. D. Gerard. 2004. Plant population affects pumpkin yield components. HortTechnology 14(3):326-331.

Fiacchino, D.C. and S.A. Walters. 2003. Influence of diploid pollenizer frequencies on triploid watermelon quality and yields. HortTechnology 13:58-61.

Maynard, D.N. 1992. Growing seedless watermelon. Univ. Fla. Coop. Ext. Serv. Fact sheet HS687. (http://edis.ifas.ufl.edu/CV006)

Maynard, D.N. and G.W. Elmstrom. 1992. Triploid watermelon production practices and varieties. Acta Hort. 318:169-173.

Motsenbocker, C. E. and R. A. Arancibia. 2002. In-row spacing influences triploid watermelon yield and crop value. HortTechnology 12(3):437-440

NeSmith, S. and J. Duval. 2001. Fruit set of triploid watermelon as a function of distance from a diploid pollenizer. HortScience 36(1):60-61.

Sanders, D. C., J. D. Cure, J. R. Schultheis. 1999. Yield response of watermelon to planting density, planting pattern, and polyethylene mulch. HortScience 34(7):1221-1223

U.S. Department of Agriculture. 2005, 2006. National watermelon report. U.S. Dept. Agr. Agricultural Marketing Service. (http://www.ams.usda.gov) Thomasville, Ga. 


\begin{tabular}{|l|l|l|l|l|l|}
\hline $\mathbf{D}$ & $\mathbf{T}$ & $\mathbf{T}$ & $\mathbf{T}$ & $\mathbf{D}$ & $\mathbf{T}$ \\
\hline $\mathbf{D}$ & $\mathbf{T}$ & $\mathbf{T}$ & $\mathbf{T}$ & $\mathbf{D}$ & $\mathbf{T}$ \\
\hline $\mathbf{D}$ & $\mathbf{T}$ & $\mathbf{T}$ & $\mathbf{T}$ & $\mathbf{D}$ & $\mathbf{T}$ \\
\hline $\mathbf{D}$ & $\mathbf{T}$ & $\mathbf{T}$ & $\mathbf{T}$ & $\mathbf{D}$ & $\mathbf{T}$ \\
\hline
\end{tabular}

Figure 1. Traditional pollenizer arrangement

\begin{tabular}{|c|c|c|c|c|c|}
\hline $\mathbf{T}$ & $\mathbf{P}$ & $\mathbf{T}$ & $\mathbf{T}$ & $\mathbf{T}$ & $\mathbf{P}$ \\
\hline $\mathbf{T}$ & $\mathbf{T}$ & $\mathbf{P}$ & $\mathbf{T}$ & $\mathbf{T}$ & $\mathbf{T}$ \\
\hline $\mathbf{T}$ & $\mathbf{T}$ & $\mathbf{T}$ & $\mathbf{P}$ & $\mathbf{T}$ & $\mathbf{T}$ \\
\hline $\mathbf{P}$ & $\mathbf{T}$ & $\mathbf{T}$ & $\mathbf{T}$ & $\mathbf{P}$ & $\mathbf{T}$ \\
\hline $\mathbf{T}$ & $\mathbf{P}$ & $\mathbf{T}$ & $\mathbf{T}$ & $\mathbf{T}$ & $\mathbf{P}$ \\
\hline $\mathbf{T}$ & $\mathbf{T}$ & $\mathbf{P}$ & $\mathbf{T}$ & $\mathbf{T}$ & $\mathbf{T}$ \\
\hline $\mathbf{T}$ & $\mathbf{T}$ & $\mathbf{T}$ & $\mathbf{P}$ & $\mathbf{T}$ & $\mathbf{T}$ \\
\hline $\mathbf{P}$ & $\mathbf{T}$ & $\mathbf{T}$ & $\mathbf{T}$ & $\mathbf{P}$ & $\mathbf{T}$ \\
\hline \multicolumn{7}{|c|}{$\mathbf{D}=$ Diploid T } \\
\hline
\end{tabular}

Figure 2. In-row pollenizer arrangement with 1:3 pollenizer to triploid ratio 
Table 1. Commercially available diploid pollenizers

\begin{tabular}{|c|c|c|c|}
\hline Cultivar & Source & Vine Type & Fruit Type \\
\hline 'Companion' & Seminis & $\begin{array}{l}\text { Short internode, compact plant with } \\
\text { medium foliage }\end{array}$ & Oblong gray \\
\hline 'Jenny' & Nunhems & $\begin{array}{l}\text { Reduced vines, increased branching, } \\
\text { thinner foliage }\end{array}$ & Round jubilee type stripe \\
\hline 'Mickylee' & $\begin{array}{c}\text { Various - Abbott \& Cobb, } \\
\text { Willhite, etc. }\end{array}$ & Standard & Round gray \\
\hline 'Minipool' & Hazera & Slightly reduced standard type vines & Round gray \\
\hline 'Patron' & Zeraim Gedera & $\begin{array}{l}\text { Reduced vines, increased branching, } \\
\text { thinner foliage }\end{array}$ & $\begin{array}{c}\text { Gray with thin green } \\
\text { striping }\end{array}$ \\
\hline 'Pinnacle' & Southwestern Seed & $\begin{array}{l}\text { Reduced vines, increased branching, } \\
\text { thinner foliage }\end{array}$ & Jubilee type stripe \\
\hline 'Sidekick' & Harris Moran & $\begin{array}{l}\text { Reduced vines, increased branching, } \\
\text { thinner foliage }\end{array}$ & $\begin{array}{l}\text { Crimson sweet with dark } \\
\text { background, very small } \\
\text { size }\end{array}$ \\
\hline SP-1 & Syngenta & $\begin{array}{c}\text { Highly branched, thin vines with } \\
\text { reduced leaves }\end{array}$ & $\begin{array}{l}\text { Round gray with thin } \\
\text { green striping }\end{array}$ \\
\hline \multicolumn{4}{|c|}{$\begin{array}{l}\text { Z Pollenizer refers to the plant that provides the pollen. This term should not be confused with "pollinator" which refers to the } \\
\text { insect vector (bees) that transports the pollen from the male flower to the female flower. } \\
\text { } \text { Sources are provided for information purposes and should not be considered endorsements. Similar cultivars may be found } \\
\text { in other reputable sources. }\end{array}$} \\
\hline
\end{tabular}

Table 2. Seedless watermelon yield data from Blackville, SC. 2005

\begin{tabular}{|c|c|}
\hline Pollenizer Cultivar & Total Weight (Ibs/acre) $^{y}$ \\
\hline Jenny & $60326 a^{y}$ \\
\hline SP-1 & 57093 a \\
\hline Mickylee & 55141 a \\
\hline Tri-X Palomar $^{2}$ & $9369 \mathrm{~b}$ \\
\hline \multicolumn{2}{|c|}{$\begin{array}{l}{ }^{z} \text { Triploid cultivar serving as check against pollen contamination from neighboring plots } \\
\text { y Means with the same letter are not significantly different at }(P=0.05) \text { by Duncan's multiple range test. }\end{array}$} \\
\hline
\end{tabular}


Table 3. Seedless watermelon yield data from Citra, Fl; Quincy, Fl; and Blackville, SC. 2006

\begin{tabular}{||cc||}
\hline \hline Pollenizer Cultivar & \multicolumn{1}{c||}{ Total Weight (lbs/acre) } \\
\hline Sidekick & $58252 \mathrm{a}^{\mathrm{z}}$ \\
Patron & $56854 \mathrm{a} \mathrm{b}$ \\
SP-1 & $55148 \mathrm{a} \mathrm{b}$ \\
Jenny & $55135 \mathrm{a} \mathrm{b}$ \\
Mickylee & $53213 \mathrm{a} \mathrm{b} \mathrm{c}$ \\
Pinnacle & $47618 \mathrm{~b} \mathrm{c}$ \\
Companion & $44621 \mathrm{c}$ \\
Tri-X Palomar $^{\mathrm{z}}$ & $7629 \mathrm{~d}$ \\
$\mathrm{z}$ LSD at $P=0.05$ & \\
${ }^{\mathrm{Y}}$ Triploid cultivar serving as check against pollen contamination from neighboring plots. \\
\hline \hline
\end{tabular}

Table 4. Hollow heart measurements of seedless watermelons from Quincy, FL. 2006

\begin{tabular}{|c|c|}
\hline Cultivar & Hollow heart Area $\left(\text { inches }^{2}\right)^{y}$ \\
\hline Tri-X Palomar $^{z}$ & 29.0 a \\
\hline Patron & $11.6 \mathrm{~b}$ \\
\hline Jenny & $10.8 \mathrm{~b}$ \\
\hline Sidekick & $10.5 \mathrm{~b}$ \\
\hline Companion & $9.0 \mathrm{~b}$ \\
\hline Mickylee & $8.4 \mathrm{~b}$ \\
\hline SP-1 & $8.3 \mathrm{~b}$ \\
\hline $\begin{array}{l}\text { Pinnacle } \\
\text { Pin }\end{array}$ & $5.8 \mathrm{~b}$ \\
\hline \multicolumn{2}{|c|}{$\begin{array}{l}z \text { Triploid cultivar serving as check against pollen contamination from neighboring plots. } \\
{ }^{Y} \text { Means followed by the same letter are not significantly different at }(P=0.05) \text { by Duncan's multiple range test }\end{array}$} \\
\hline
\end{tabular}

Table 5. $P$ Values for factors affecting total seedless watermelon yield at all locations in 2006

\begin{tabular}{||cc|}
\hline \hline Factor & P Value \\
\hline Location & $<0.0001$ \\
Cultivar & $<0.0001$ \\
Location * Variety & .4280 \\
\hline \hline
\end{tabular}

